\title{
First Report of Stem and Bulb Nematode Ditylenchus dipsaci on Garlic in New Mexico
}

\begin{abstract}
Jason M. French, Department of Extension Plant Sciences; Jacki Beacham and Amanda Garcia, Department of Entomology, Plant Pathology, and Weed Science; Natalie P. Goldberg, Department of Extension Plant Sciences; and Stephen H. Thomas and Stephen F. Hanson, Department of Entomology Plant Pathology and Weed Science, New Mexico State University, Las Cruces, NM 88003
\end{abstract}

Accepted for publication 28 March 2017.

Ditylenchus dipsaci is a serious temperate-climate nematode pest of over 500 plant species in over 40 plant families (Subbotin et al. 2005), including onions, garlic, and alfalfa. Among plantparasitic nematodes, it ranks fifth in economic importance and is of nearly universal international quarantine concern (Jones et al. 2013; OEPP/EPPO 2008). New Mexico is the eighth largest producer of onions in the United States, cultivating 5,200 acres with a crop value of $\$ 91$ million, making onions the third-highest grossing crop in New Mexico in 2015 (USDA-NASS). New Mexico also has a vibrant small-farm garlic industry that supplies local markets with fresh garlic and seed for producers. New Mexico has never reported an infestation of D. dipsaci and its presence could have serious ramifications for New Mexico's onion, garlic, and alfalfa producers.

In May of 2015, garlic plants (Allium sativum) from a home garden in Dona Ana Co. were submitted to the Plant Diagnostic Clinic at New Mexico State University. The grower reported poor growth in $\sim 30 \%$ of 1200 plants originating from seed purchased in southern New Mexico. Early symptoms included chlorosis, wilting, and poor root and bulb development. As the disease progressed, roots turned brown, were easily separated from the bulb, and older foliage had collapsed and turned straw colored (Fig. 1). Microscopic examination showed large numbers of nematodes present in symptomatic garlic plants.

Two regulatory samples with similar symptoms were submitted to the USDA-APHIS Nematode Containment Facility \#76. Nematodes from both the homeowner and regulatory samples were morphologically consistent with descriptions of $D$. dipsaci, possessing small stylets, small but distinct metacorpus, and conical, pointed, slightly asymmetric tails (Sturhan and Brzeski 1991) (Fig. 2). Males exhibited prominent retracted spicules and long, slender bursae. Measurements taken from 10 mature male and female nematodes produced the following mean lengths: $1.01 \mathrm{~mm}\left({ }^{\star}\right)$ and $1.06 \mathrm{~mm}(\$)$, which are consistent with values reported for D. dispsaci.

The DNA sequence of the ITS-1 region, which is useful for identification of Ditylenchus species (Subbotin et al. 2005), was determined for 22 individual nematodes picked from infested garlic samples. The ITS-1 region sequences were identical between all 22 individuals, indicating the population of nematodes infesting the garlic was clonal. BLAST analysis and pairwise comparisons showed that the ITS region sequences were $100 \%$ identical to

Corresponding author: Stephen F. Hanson; E-mail: shanson@nmsu.edu

(C) 2017 The American Phytopathological Society numerous $D$. dipsaci sequences in GenBank, with the next closest related species being D. gigas (GenBank Accession No. HQ219239) and D. weischeri (AF396322), both being 95\% identical. The New Mexico garlic nematode ITS-1 sequence was only 46 to $57 \%$ identical to reported $D$. destructor sequences (DQ471334 and HQ235677).

Taken together, the symptoms present, microscopic characterization, and ITS-1 sequence data all indicate that the garlic samples were infested Ditylenchus dipsaci making this the first known report of this pest in New Mexico. This discovery is highly significant as $D$. dipsaci can be a persistent pest (Seinhorst 1956) that has the potential to cause significant economic losses on agronomically important hosts grown in the state and region including onion, garlic, and alfalfa. The longevity of this pest in the soil and international trade issues will also be concerns for producers going forward. Based on information from the grower, it appears that this is an isolated introduction from infested plant material which can potentially be contained as the presence of $D$. dipsaci was discovered before any material was harvested or distributed. Monitoring of production areas in the region will be performed to determine if this

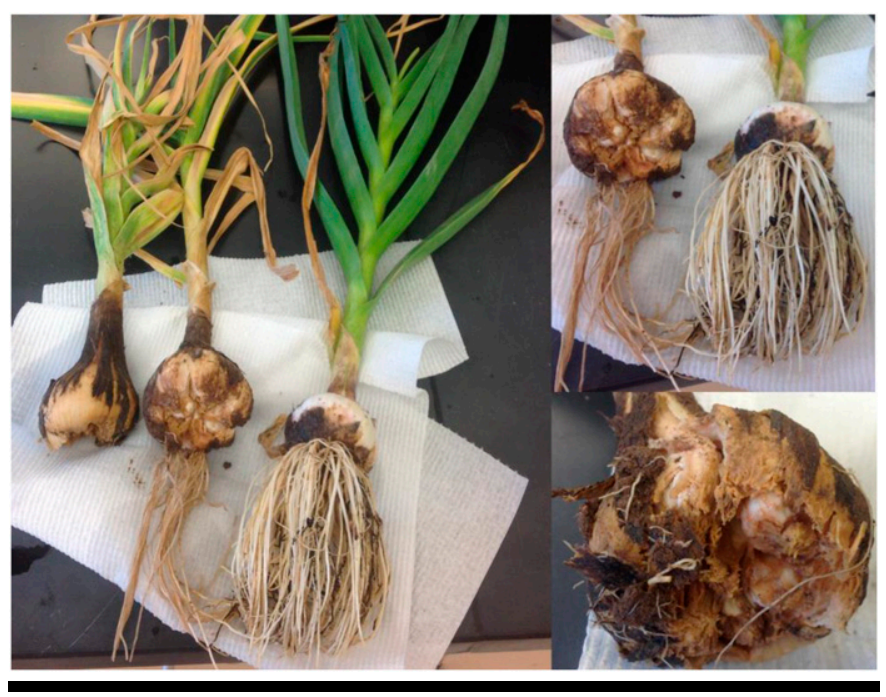

FIGURE 1

Left: From left to right, two garlic plants exhibiting severe symptoms of Ditylenchus dipsaci infection compared with healthy plant on the right. The plants exhibit leaf chlorosis and necrosis with a progressive loss of functioning roots. Close-up photos of bulb symptoms shown at right. 


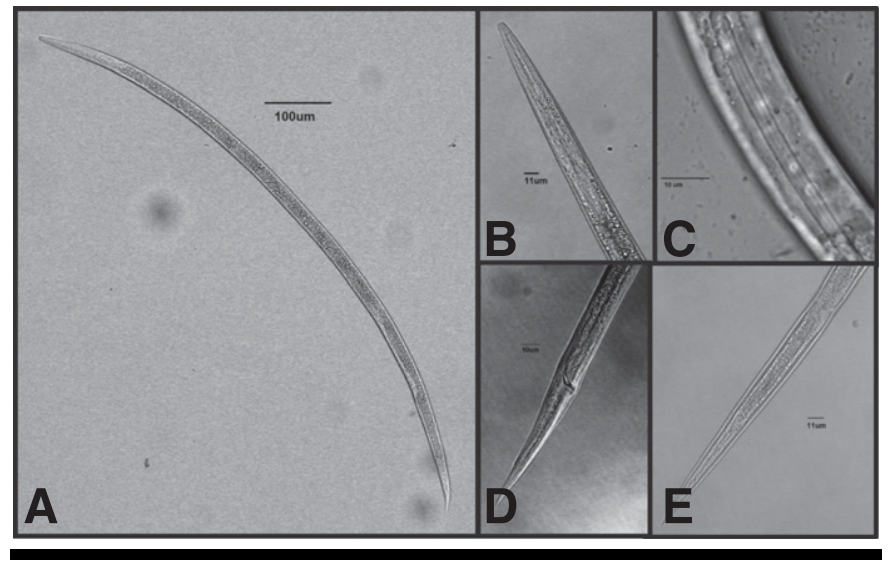

FIGURE 2

Microscopic photos of representative nematodes recovered from symptomatic garlic plants: (A) female; (B) esophagus with metacorpus and stylet; (C) 4 incisures in lateral field; (D and $\mathbf{E})$ male and female tail shapes, respectively. was an isolated and contained introduction or if this important pest has become established in New Mexico.

\section{Literature Cited}

Jones, J. T., Haegeman, A., Danchin, E. G. J., Gaur, H. S., Helder, J., Jones, M. G. K., Kikuchi, T., Manzanilla-Lopez, R., Palomares-Ruis, J. E., Wesemael, W. M. L., and Perry, R. N. 2013. Top 10 plant-parasitic nematodes in molecular plant pathology. Mol. Plant Pathol. 14:946-961.

OEPP/EPPO. 2008. Ditylenchus destructor and Ditylenchus dipsaci. Bulletin 38:363-373.

Seinhorst, J. W. 1956. Population studies on stem eelworms (Ditylenchus dipsaci). Nematologica 1:159-164.

Sturhan, D., and Brzeski, M. W. 1991. Stem and bulb nematodes, Ditylenchus spp. Pages 423-464 in: Manual of Agricultural Helminthology. W. R. Nickle, ed. Marcel Dekker, New York.

Subbotin, S. A., Madani, M., Krall, E., Sturhan, D., and Moens, M. 2005. Molecular diagnostics, taxonomy, and phylogeny of the stem nematode Ditylenchus dipsaci species complex based on the sequences of the internal transcribed spacer-rDNA. Phytopathology 95:13081315. 